\title{
Effect of seed coating, storage periods and storage containers on soybean (Glycine max (L.) Merrill) seed quality under ambient conditions
}

\author{
Ajay Puri Goswami ${ }^{1 *}$, Karuna Vishunavat ${ }^{2}$, Chander Mohan ${ }^{3}$ and Sanjeev Ravi ${ }^{4}$ \\ ${ }^{1}$ Department of Seed Science and Technology, Govind Ballabh Pant University of Agriculture and Technology, \\ Pantnagar-263145 (Uttarakhand) INDIA \\ Present address: Shivalik Institute of Professional Studies, Shimla bypass Road, Shiniwala, Sherpur, Dehradun- \\ 248197 (Uttarakhand), INDIA \\ ${ }^{2}$ Department of Plant Pathology, Govind Ballabh Pant University of Agriculture and Technology, Pantnagar- \\ 263145 (Uttarakhand), INDIA \\ ${ }^{3}$ Uttarakhand Seeds and Tarai Development Corporation, Udham Singh Nagar-263146 (Uttarakhand), INDIA \\ ${ }^{4}$ Uttarakhand University of Horticulture and Forestry, Bharsar, Pauri Garhwal-246123 (Uttarakhand), INDIA \\ *Corresponding author. E-mail: ajaypuristudent@gmail.com
}

Received: July 11, 2016; Revised received: January 10, 2017; Accepted: February 24, 2017

Abstract: Soybean seed is classified as "poor storer" as it loses viability under warm and humid conditions and is invaded by storage fungi. The seed of soybean variety PS 1347, obtained from Breeder Seed Production Centre, G. B. Pant University of Agriculture and Technology, Pantnagar was used for storage study. Root length (cm), shoot length $(\mathrm{cm})$, seedling fresh weight $(\mathrm{g})$ and seedling dry weight $(\mathrm{g})$ decreases with the increase in seed storage periods. Out of all chemical treatments, Flowable thiram @ $2.4 \mathrm{ml} / \mathrm{kg}\left(\mathrm{T}_{2}\right)$ and Polymer + vitavax $200 @ 2 \mathrm{~g} / \mathrm{kg}$ seed $\left(T_{5}\right)$ were found effective to maintain Seedling root length, shoot length, seedling fresh weight and seedling dry weight by producing vigorous seedlings. Seeds stored in cloth bags exhibited higher seed infection than in seed stored in polythene bags, irrespective of seed treatment and period of storage. Treatment $\mathrm{T}_{4}$ (Vitavax $200 @ 2 \mathrm{~g} / \mathrm{kg}$ seed)and $T_{5}$ (Polymer + vitavax $200 @ 2 \mathrm{~g} / \mathrm{kg}$ seed) exhibited minimum percent seed infection of Aspergillus flavus. Cloth bag was not found safe for longer storage of soybean seeds under ambient storage at Pantnagar.

Keywords: Soybean, Storage periods, Storage container, Treatments

\section{INTRODUCTION}

Soybean (Glycine max (L.) Merrill) is one of the important sources of vegetable oil $(20 \%)$ and plant protein $(40 \%)$. It is a member of family Leguminoceae, sub family papilionaideae, $2 \mathrm{n}=40$ is supposed to have originated in China. It is the third important oilseed crop next to groundnut and mustard (Kakde et al. 2012). In India, harvested area of soybean is 10.908 million hectare with production of 10.528 million tonnes (F.A.O., 2014), In Uttarakhand, it is grown over 12757 hectare having production of $15997 \mathrm{mt}$ (Directorate of Agriculture, Uttarakhand, 2015). Soybean is a poor storer because it loses viability and invaded by storage fungi (Nandi et al, 1982). Storage temperature and relative humidity are main factors which affect the seed quality. Seed aging had significant effects on electrical conductivity and seed germination traits (Mohammadi et al., 2011). The rate at which seed aging take place depends on ability of seeds to resist degradation changes, specific to each plant species (Tubic et al., 2010). Storability of seeds is mainly a genetically regulated character and is influenced by quality of the seed at the time of storage, pre- storage history of seed (environmental factors during pre and post-harvest stages), moisture content, relative humidity \& temperature of storage environment and biotic causes (Shelar et al., 2008). Lipid auto-oxidation and increase of free fatty acid content during storage are the most often mentioned reasons for accelerated damage of seed of oily plant species (Motlagh and Shaban, 2014). Maintenance of seed quality during storage is an important aspect. Soybean seeds have poor storability. Keeping about the problem of storability in soybean seed in mind, the present study was conducted to evaluate the effect of different seed coating chemicals and storage containers at different storage periods on seed quality parameters.

\section{MATERIALS AND METHODS}

This study was conducted during the year 2013-14 in the Department of Plant Pathology, G. B. Pant University of Agriculture and Technology, Pantnagar, Uttarakhand. The seeds of soybean variety PS 1347, obtained from Breeder Seed Production Centre, G.B. Pant University of Agriculture and Technology, Pantnagar were used. Seeds were subjected to 6 coating 
treatments viz., $\mathrm{T}_{0}$ (Control), $\mathrm{T}_{1}$ (Polymer coating (Polykote@3 ml $/ \mathrm{kg}$ of seed), T2 (Flowable thiram@ $2.4 \mathrm{ml} / \mathrm{kg}$ ), $\mathrm{T}_{3}$ (Polymer (Polykote@ $3 \mathrm{ml} / \mathrm{kg}$ of seed) + Flowable thiram@2.4 ml/kg seed), T4 (Vitavax 200 (a) 2 g/kg seed), T 5 (Polymer + Vitavax $200 @ 2$ g/kg seed) before storage. Treated seeds were stored in two types of containers viz., cloth bag $\left(\mathrm{C}_{1}\right)$ (Moisture pervious) and polythene bag $\left(\mathrm{C}_{2}\right)$ (700 gauge) (Moisture impervious) under ambient storage conditions. Observations on different seed parameters viz., root length $(\mathrm{cm})$, shoot length $(\mathrm{cm})$, seedling dry weight $(\mathrm{g})$, vigour index-II and Aspergillus flavus percentage were taken at bimonthly intervals $\left(\mathrm{P}_{1}=\right.$ after 2 months, $\mathrm{P}_{2}=$ after 4 months, $\mathrm{P}_{3}=$ after 6 months, $\mathrm{P}_{4}=$ after 8 months, $\mathrm{P}_{5}=$ after 10 months) intervals. Observation on root length, shoot length was taken at $8^{\text {th }}$ day of germination on randomly selected ten seedlings from each treatment in each replication. Seedling dry weight was taken on same seedlings selected for shoot and root length from each treatment in each replication at $8^{\text {th }}$ day. Seedlings were dried in the oven at $80{ }^{\circ} \mathrm{C}$ for 48 hours (Radha et al., 2013). The dried seedlings were weighed on electronic balance and average weight was expressed as per seedling weight (g). For detection of Aspergillus flavus infection, standard blotter method was used. In this method, three layers of sterilized blotters were jointly soaked in sterilized distilled water and placed in the Petri dishes with the help of disinfected forcep. These plates were incubated at $20 \pm 2{ }^{\circ} \mathrm{C}$ for 7 days in alternating cycles of 12 hours darkness and 12 hours light in incubator. Total of 400 seeds are tested for detection of fungi. After 7 days of incubation, seeds were examined under stereoscopic microscope and per cent seed infection was calculated (ISTA, 2002).

The statistical analysis of the data was done according to three factorial complete randomized design (CRD) and interpretation of results was based on "F-test" and critical difference (CD) at $5 \%$ level of significance (Rangaswamy, 2014).

\section{RESULTS AND DISCUSSION}

In cloth bag $\left(\mathrm{C}_{1}\right)$, no root, shoot length and seedling dry and fresh weight was observed in all treated seeds of soybean at ten months of storage $\left(\mathrm{P}_{5}\right)$. Ali et al. (2014) also found no seedling dry matter after six months of storage.

Seedling root length was found maximum at 2 months period of storage $\left(\mathrm{P}_{1}\right)$ and ranged between minimum $12.41 \mathrm{~cm}\left(\mathrm{C}_{1} \mathrm{~T}_{1}\right)$ to $14.67 \mathrm{~cm}\left(\mathrm{C}_{1} \mathrm{~T}_{5}\right)$ and decreases with an increase in storage period and found in the range $5.56 \mathrm{~cm}(\mathrm{C} 1 \mathrm{~T} 1)$ to $10.90 \mathrm{~cm}\left(\mathrm{C}_{1} \mathrm{~T}_{5}\right)$ at 8 months of storage $\left(\mathrm{P}_{4}\right)$ and no seedling root length was observed at 10 months of storage $\left(\mathrm{P}_{5}\right)$ of soybean seeds in cloth bag. These findings were in accordance to Monira et al. (2012) found that shoot and root length of seedling was lowest at the end of storage in cloth cloth bag stored seeds. Results indicate that seedling root length decreases with an advancement of storage periods. Seedling root length was found maximum at 2 months of storage $\left(\mathrm{P}_{1}\right)$ and ranged between $13.37 \mathrm{~cm}$ $\left(\mathrm{C}_{2} \mathrm{~T}_{0}\right)$ to $17.28\left(\mathrm{C}_{2} \mathrm{~T}_{5}\right)$ which fall down and lies in the range $12.66 \mathrm{~cm}\left(\mathrm{C}_{2} \mathrm{~T}_{0}\right)$ to $15.02 \mathrm{~cm}\left(\mathrm{C}_{2} \mathrm{~T}_{5}\right)$ at ten months of storage (Table 1). Seedling root length of cloth bag stored soybean seeds was found significantly lower as compared to polythene bag $\left(\mathrm{C}_{2}\right)$ stored soybean seeds and does not goes to zero due to impervious nature of polythene bag towards air. Islam et al. (2004) found that polythene bag showed better performance to maintain root length as compared with other containers.

Seedling shoot length was found maximum at 2 months period of storage $\left(\mathrm{P}_{1}\right)$ and ranged between minimum $11.64 \mathrm{~cm}\left(\mathrm{C}_{1} \mathrm{~T}_{0}\right)$ to $13.75 \mathrm{~cm}\left(\mathrm{C}_{1} \mathrm{~T}_{5}\right)$ and decreases with an increase in storage period and found in the range $5.11 \mathrm{~cm}\left(\mathrm{C}_{1} \mathrm{~T}_{1}\right)$ to $9.32 \mathrm{~cm}\left(\mathrm{C}_{2} \mathrm{~T}_{5}\right)$ at 8 months of storage $\left(\mathrm{P}_{4}\right)$ and no seedling root length was observed at 10 months of storage $\left(\mathrm{P}_{5}\right)$ of soybean seeds in cloth bag. These findings were in accordance to Monira et al. (2012) found that shoot and root length of seedling was lowest at the end of storage in cloth bag stored seeds. Seedling shoot length was found maximum at 2 months of storage $\left(\mathrm{P}_{1}\right)$ and ranged between $12.10 \mathrm{~cm}\left(\mathrm{C}_{2} \mathrm{~T}_{0}\right)$ to $15.20 \mathrm{~cm}\left(\mathrm{C}_{2} \mathrm{~T}_{5}\right)$ which fall down and lies in the range of $10.50 \mathrm{~cm}\left(\mathrm{C}_{2} \mathrm{~T}_{0}\right)$ to $12.14 \mathrm{~cm}$ $\left(\mathrm{C}_{2} \mathrm{~T}_{5}\right)$ at ten months of storage (Table 1). Seedling shoot length of cloth bag stored soybean seeds was found significantly lower as compared to polythene bag $\left(\mathrm{C}_{2}\right)$ stored soybean seeds and does not goes to zero due to impervious nature of polythene bag towards air. Results indicate that seedling shoot length of polythene bag $\left(\mathrm{C}_{2}\right)$ stored soybean seeds decreases with an advancement of storage periods but at slower rate as compared to cloth bag stored seeds. Islam et al. (2004) found that polythene bag showed better performance to maintain root length as compared with other containers.

Seedling fresh weight was found maximum at 2 months period of storage $\left(\mathrm{P}_{1}\right)$ and ranged between minimum $6.772 \mathrm{~g}\left(\mathrm{C}_{1} \mathrm{~T}_{0}\right)$ to $8.300\left(\mathrm{C}_{1} \mathrm{~T}_{2}\right)$ and decreases with an increase in storage period and found in the range $2.920 \mathrm{~g}\left(\mathrm{C}_{1} \mathrm{~T}_{3}\right)$ to $5.915 \mathrm{~g}\left(\mathrm{C}_{1} \mathrm{~T}_{5}\right)$ at 8 months of storage $\left(\mathrm{P}_{4}\right)$ and no seedling fresh weight was observed at 10 months of storage $\left(\mathrm{P}_{5}\right)$ of soybean seeds in cloth bag. Seedling fresh weight was found maximum at 2 months of storage $\left(\mathrm{P}_{1}\right)$ and ranged between $6.725 \mathrm{~g}$ $\left(\mathrm{C}_{2} \mathrm{~T}_{3}\right)$ to $8.125 \mathrm{~g}\left(\mathrm{C}_{2} \mathrm{~T}_{2}\right)$ which fall down and lies in the range of $6.050 \mathrm{~g}\left(\mathrm{C}_{2} \mathrm{~T}_{3}\right)$ to $7.451 \mathrm{~g}\left(\mathrm{C}_{2} \mathrm{~T}_{2}\right)$ at ten months of storage $\left(\mathrm{P}_{5}\right)$ (Table 1$)$. Seedling fresh weight of cloth bag stored soybean seeds was found significantly lower as compared to polythene bag $\left(\mathrm{C}_{2}\right)$ stored soybean seeds and does not goes to zero due to impervious nature of polythene bag towards air due to this the ageing process may be slow in polythene bag. Re- 
Ajay Puri Goswami et al. / J. Appl. \& Nat. Sci. 9 (1): 598 - 602 (2017)

Table 1. Effect of seed coating, storage periods and storage containers on soybean (Glycine max (L.) Merrill) seed quality under ambient conditions.

\begin{tabular}{|c|c|c|c|c|c|}
\hline Combinations & $\begin{array}{l}\text { Root length } \\
\text { (cm) }\end{array}$ & $\begin{array}{c}\text { Shoot length } \\
\text { (cm) }\end{array}$ & $\begin{array}{l}\text { Seedling fresh } \\
\text { weight (g) }\end{array}$ & $\begin{array}{l}\text { Seedling dry } \\
\text { weight (g) }\end{array}$ & Aspergillus flavus (\%) \\
\hline $\mathrm{C}_{1} \mathrm{~T}_{0} \mathrm{P}_{1}$ & 13.16 & 11.64 & 6.772 & 0.423 & 19.75 \\
\hline $\mathrm{C}_{1} \mathrm{~T}_{0} \mathrm{P}_{2}$ & 12.06 & 11.39 & 6.738 & 0.411 & 49.50 \\
\hline $\mathrm{C}_{1} \mathrm{~T}_{0} \mathrm{P}_{3}$ & 11.79 & 11.18 & 6.672 & 0.340 & 69.50 \\
\hline $\mathrm{C}_{1} \mathrm{~T}_{0} \mathrm{P}_{4}$ & 7.35 & 5.86 & 3.365 & 0.232 & 69.25 \\
\hline $\mathrm{C}_{1} \mathrm{~T}_{0} \mathrm{P}_{5}$ & 0.00 & 0.00 & 0.00 & 0.00 & 73.25 \\
\hline $\mathrm{C}_{1} \mathrm{~T}_{1} \mathrm{P}_{1}$ & 12.41 & 11.86 & 7.462 & 0.436 & 18.75 \\
\hline $\mathrm{C}_{1} \mathrm{~T}_{1} \mathrm{P}_{2}$ & 12.19 & 11.05 & 6.850 & 0.405 & 55.25 \\
\hline $\mathrm{C}_{1} \mathrm{~T}_{1} \mathrm{P}_{3}$ & 11.65 & 10.69 & 6.748 & 0.339 & 66.25 \\
\hline $\mathrm{C}_{1} \mathrm{~T}_{1} \mathrm{P}_{4}$ & 5.56 & 5.11 & 5.611 & 0.134 & 70.50 \\
\hline $\mathrm{C}_{1} \mathrm{~T}_{1} \mathrm{P}_{5}$ & 0.00 & 0.00 & 0.00 & 0.00 & 75.50 \\
\hline $\mathrm{C}_{1} \mathrm{~T}_{2} \mathrm{P}_{1}$ & 14.41 & 13.30 & 8.300 & 0.453 & 14.25 \\
\hline $\mathrm{C}_{1} \mathrm{~T}_{2} \mathrm{P}_{2}$ & 12.40 & 13.22 & 7.420 & 0.440 & 33.25 \\
\hline $\mathrm{C}_{1} \mathrm{~T}_{2} \mathrm{P}_{3}$ & 12.30 & 13.03 & 7.140 & 0.426 & 43.25 \\
\hline $\mathrm{C}_{1} \mathrm{~T}_{2} \mathrm{P}_{4}$ & 9.56 & 8.19 & 5.750 & 0.226 & 49.50 \\
\hline $\mathrm{C}_{1} \mathrm{~T}_{2} \mathrm{P}_{5}$ & 0.00 & 0.00 & 0.00 & 0.00 & 61.00 \\
\hline $\mathrm{C}_{1} \mathrm{~T}_{3} \mathrm{P}_{1}$ & 13.76 & 12.01 & 7.319 & 0.417 & 23.25 \\
\hline $\mathrm{C}_{1} \mathrm{~T}_{3} \mathrm{P}_{2}$ & 12.59 & 11.55 & 6.646 & 0.413 & 40.75 \\
\hline $\mathrm{C}_{1} \mathrm{~T}_{3} \mathrm{P}_{3}$ & 12.15 & 11.48 & 6.436 & 0.375 & 61.00 \\
\hline $\mathrm{C}_{1} \mathrm{~T}_{3} \mathrm{P}_{4}$ & 7.57 & 6.36 & 2.920 & 0.101 & 63.50 \\
\hline $\mathrm{C}_{1} \mathrm{~T}_{3} \mathrm{P}_{5}$ & 0.00 & 0.00 & 0.00 & 0.00 & 70.75 \\
\hline $\mathrm{C}_{1} \mathrm{~T}_{4} \mathrm{P}_{1}$ & 12.77 & 12.64 & 7.476 & 0.450 & 0.50 \\
\hline $\mathrm{C}_{1} \mathrm{~T}_{4} \mathrm{P}_{2}$ & 12.68 & 12.61 & 6.770 & 0.447 & 0.75 \\
\hline $\mathrm{C}_{1} \mathrm{~T}_{4} \mathrm{P}_{3}$ & 12.48 & 12.52 & 6.325 & 0.403 & 4.75 \\
\hline $\mathrm{C}_{1} \mathrm{~T}_{4} \mathrm{P}_{4}$ & 10.45 & 9.27 & 3.250 & 0.117 & 5.50 \\
\hline $\mathrm{C}_{1} \mathrm{~T}_{4} \mathrm{P}_{5}$ & 0.00 & 0.00 & 0.00 & 0.00 & 5.50 \\
\hline $\mathrm{C}_{1} \mathrm{~T}_{5} \mathrm{P}_{1}$ & 14.67 & 13.75 & 7.520 & 0.462 & 0.50 \\
\hline $\mathrm{C}_{1} \mathrm{~T}_{5} \mathrm{P}_{2}$ & 13.05 & 13.74 & 7.195 & 0.439 & 0.50 \\
\hline $\mathrm{C}_{1} \mathrm{~T}_{5} \mathrm{P}_{3}$ & 12.52 & 13.15 & 7.052 & 0.407 & 3.75 \\
\hline $\mathrm{C}_{1} \mathrm{~T}_{5} \mathrm{P}_{4}$ & 10.90 & 9.32 & 5.915 & 0.250 & 4.50 \\
\hline $\mathrm{C}_{1} \mathrm{~T}_{5} \mathrm{P}_{5}$ & 0.00 & 0.00 & 0.00 & 0.00 & 6.00 \\
\hline $\mathrm{C}_{2} \mathrm{~T}_{0} \mathrm{P}_{1}$ & 13.37 & 12.10 & 6.759 & 0.435 & 7.50 \\
\hline $\mathrm{C}_{2} \mathrm{~T}_{0} \mathrm{P}_{2}$ & 13.19 & 11.87 & 6.603 & 0.422 & 15.50 \\
\hline $\mathrm{C}_{2} \mathrm{~T}_{0} \mathrm{P}_{3}$ & 12.72 & 11.44 & 6.451 & 0.385 & 20.25 \\
\hline $\mathrm{C}_{2} \mathrm{~T}_{0} \mathrm{P}_{4}$ & 12.66 & 10.71 & 6.413 & 0.356 & 23.25 \\
\hline $\mathrm{C}_{2} \mathrm{~T}_{0} \mathrm{P}_{5}$ & 12.66 & 10.50 & 6.392 & 0.336 & 23.50 \\
\hline $\mathrm{C}_{2} \mathrm{~T}_{1} \mathrm{P}_{1}$ & 16.22 & 13.09 & 7.628 & 0.450 & 6.25 \\
\hline $\mathrm{C}_{2} \mathrm{~T}_{1} \mathrm{P}_{2}$ & 14.36 & 13.06 & 7.373 & 0.459 & 17.50 \\
\hline $\mathrm{C}_{2} \mathrm{~T}_{1} \mathrm{P}_{3}$ & 13.42 & 12.50 & 7.082 & 0.401 & 21.50 \\
\hline $\mathrm{C}_{2} \mathrm{~T}_{1} \mathrm{P}_{4}$ & 13.41 & 11.26 & 7.041 & 0.360 & 22.75 \\
\hline $\mathrm{C}_{2} \mathrm{~T}_{1} \mathrm{P}_{5}$ & 13.12 & 11.54 & 6.937 & 0.345 & 23.50 \\
\hline $\mathrm{C}_{2} \mathrm{~T}_{2} \mathrm{P}_{1}$ & 15.93 & 13.50 & 8.125 & 0.492 & 4.00 \\
\hline $\mathrm{C}_{2} \mathrm{~T}_{2} \mathrm{P}_{2}$ & 15.87 & 13.49 & 7.836 & 0.466 & 12.25 \\
\hline $\mathrm{C}_{2} \mathrm{~T}_{2} \mathrm{P}_{3}$ & 15.32 & 12.77 & 7.625 & 0.446 & 15.50 \\
\hline $\mathrm{C}_{2} \mathrm{~T}_{2} \mathrm{P}_{4}$ & 15.12 & 11.79 & 7.518 & 0.419 & 17.50 \\
\hline $\mathrm{C}_{2} \mathrm{~T}_{2} \mathrm{P}_{5}$ & 14.34 & 11.81 & 7.451 & 0.389 & 20.25 \\
\hline $\mathrm{C}_{2} \mathrm{~T}_{3} \mathrm{P}_{1}$ & 15.64 & 13.22 & 6.725 & 0.441 & 8.25 \\
\hline $\mathrm{C}_{2} \mathrm{~T}_{3} \mathrm{P}_{2}$ & 15.34 & 12.94 & 6.653 & 0.421 & 15.25 \\
\hline $\mathrm{C}_{2} \mathrm{~T}_{3} \mathrm{P}_{3}$ & 13.69 & 11.97 & 6.287 & 0.402 & 21.00 \\
\hline $\mathrm{C}_{2} \mathrm{~T}_{3} \mathrm{P}_{4}$ & 12.93 & 11.55 & 6.152 & 0.356 & 20.25 \\
\hline $\mathrm{C}_{2} \mathrm{~T}_{3} \mathrm{P}_{5}$ & 12.74 & 11.41 & 6.050 & 0.312 & 21.50 \\
\hline $\mathrm{C}_{2} \mathrm{~T}_{4} \mathrm{P}_{1}$ & 15.11 & 13.18 & 7.580 & 0.466 & 0.25 \\
\hline $\mathrm{C}_{2} \mathrm{~T}_{4} \mathrm{P}_{2}$ & 14.44 & 12.76 & 7.095 & 0.441 & 0.50 \\
\hline $\mathrm{C}_{2} \mathrm{~T}_{4} \mathrm{P}_{3}$ & 13.48 & 12.68 & 7.077 & 0.403 & 0.75 \\
\hline $\mathrm{C}_{2} \mathrm{~T}_{4} \mathrm{P}_{4}$ & 13.11 & 11.88 & 7.068 & 0.382 & 1.00 \\
\hline $\mathrm{C}_{2} \mathrm{~T}_{4} \mathrm{P}_{5}$ & 12.75 & 11.78 & 6.875 & 0.342 & 1.00 \\
\hline $\mathrm{C}_{2} \mathrm{~T}_{5} \mathrm{P}_{1}$ & 17.28 & 15.20 & 7.937 & 0.497 & 0.25 \\
\hline $\mathrm{C}_{2} \mathrm{~T}_{5} \mathrm{P}_{2}$ & 16.81 & 15.07 & 7.577 & 0.444 & 0.50 \\
\hline $\mathrm{C}_{2} \mathrm{~T}_{5} \mathrm{P}_{3}$ & 15.48 & 13.86 & 7.460 & 0.423 & 0.50 \\
\hline $\mathrm{C}_{2} \mathrm{~T}_{5} \mathrm{P}_{4}$ & 15.05 & 12.36 & 7.290 & 0.398 & 0.50 \\
\hline $\mathrm{C}_{2} \mathrm{~T}_{5} \mathrm{P}_{5}$ & 15.02 & 12.14 & 7.242 & 0.367 & 0.75 \\
\hline $\mathrm{SEm} \pm$ & 0.289 & 0.202 & 0.206 & 0.130 & 0.519 \\
\hline CD 5\% & 0.80 & 0.56 & 0.576 & 0.036 & 1.44 \\
\hline
\end{tabular}

Container $(\mathrm{C})$ : Cloth Bag $\left(\mathrm{C}_{1}\right)$ and Polythene bag $\left(\mathrm{C}_{2}\right)$ (700 gauge), Seed coating treatments: $\mathrm{T}_{0}(\mathrm{Control}), \mathrm{T}_{1}$ (Polymer coating (Polykote @, $3 \mathrm{ml} / \mathrm{kg}$ of seed), $\mathrm{T}_{2}$ (Flowable thiram @ $2.4 \mathrm{ml} / \mathrm{kg}$ ), T 3 (Polymer (Polykote @ $3 \mathrm{ml} / \mathrm{kg}$ of seed) + Flowable thiram @ $2.4 \mathrm{ml} / \mathrm{kg}$ seed), $\mathrm{T}_{4}$ (Vitavax $200 @ 2 \mathrm{~g} / \mathrm{kg}$ seed), $\mathrm{T}_{5}$ (Polymer + Vitavax $200 @ 2 \mathrm{~g} / \mathrm{kg}$ seed) Storage periods: $\mathrm{P}_{1}$ (After 2 months), $\mathrm{P}_{2}$ (After 4 months), $\mathrm{P}_{3}$ (After 6 months), $\mathrm{P}_{4}$ (After 8 months), $\mathrm{P}_{5}$ (After 10 months) 
sults indicate that seedling fresh weight of polythene bag $\left(\mathrm{C}_{2}\right)$ stored soybean seeds decreases with an advancement of storage periods but at slower rate as compared to cloth bag stored seeds and treatment $\mathrm{T}_{2}$ was found to the best as it exhibited maximum fresh weight of seedling at the end of storage and found at par with treatment T5. Islam et al. (2004) found that polythene bag showed better performance to maintain root length as compared with other containers. Kandil et al. (2013) reported that seedling fresh weight and dry weight decreases with the aging of soybean cultivars.

Seedling dry weight decreases with an increase in storage duration and this decrease may depend on type of storage containers and treatments. In cloth bag $\left(\mathrm{C}_{1}\right)$, seedling dry weight was found highest after 2 months of storage $\left(\mathrm{P}_{1}\right)$ in $\mathrm{T}_{5}(0.462 \mathrm{~g})$ and minimum in $\mathrm{T}_{3}$ $(0.417 \mathrm{~g})$ which decreases over period of storage and after 8 months of storage lied in the range $0.101 \mathrm{~g}\left(\mathrm{~T}_{3}\right)$ to $0.250 \mathrm{~g}\left(\mathrm{~T}_{5}\right)$. Seedling fresh weight in all treatments including control reduced with an increase in storage period. After 2 months of storage $\left(\mathrm{P}_{1}\right)$ in polythene bags $\left(\mathrm{C}_{2}\right)$ seedling dry weight ranged between $0.435 \mathrm{~g}$ $\left(\mathrm{T}_{0}\right)$ to $0.497 \mathrm{~g}\left(\mathrm{~T}_{5}\right)$ this decrease with storage periods. Seedling dry weight, after 10 months of storage periods $\left(\mathrm{P}_{5}\right)$ in polythene bag $\left(\mathrm{C}_{2}\right)$ stored seeds were found in the range from $0.312 \mathrm{~g}\left(\mathrm{~T}_{3}\right)$ to $0.389 \mathrm{~g}$ (T2). Thus, in polythene bag $\left(\mathrm{C}_{2}\right)$ at all storage periods, treatments $\mathrm{T}_{2}$ and $\mathrm{T}_{5}$ were found to have significantly higher seedling dry weight (Table 1). These findings were in close agreement to Baig et al. (2012) who found that soybean seeds treated with vitavax coupled with polymer $(5 \mathrm{~g} / \mathrm{kg})$ recorded higher dry weight of seedling throughout the storage. In all treatments and in both container the seedling dry weight decreases as storage period increases but at lower rate in polythene bag as compared to cloth bag. Ali et al. (2014) found that seedling dry matter decreased with increased initial seed moisture content irrespective of storage containers used.

The percent seed infection increased with an increase in storage period in both the containers but the increase rate was different in both the containers. The percent seed infection was lowest at $\mathrm{P}_{1}$ in all the treatments as compared to control. Among different treatments the maximum $(75.50 \%)$ percent Aspergillus flavus infection was in $\mathrm{C}_{1} \mathrm{~T}_{1}$ at $\mathrm{P}_{5}$ period of storage followed in $\mathrm{C}_{1} \mathrm{~T}_{0}(73.25 \%)$ after ten months of storage $\left(\mathrm{P}_{5}\right)$. The percent Aspergillus flavus infection was considerably low $5.50 \%$ and $6.00 \%$ in $\mathrm{C}_{1} \mathrm{~T}_{4} \mathrm{P}_{5}$ and $\mathrm{C}_{1} \mathrm{~T}_{5} \mathrm{P}_{5}$ respectively, indicating the significant effect of seed treatment on Aspergillus flavus infection in storage. However, treatment $\mathrm{T}_{1}$ exhibited higher Aspergillus flavus infection at $\mathrm{C}_{2} \mathrm{P}_{5}(75.50 \%)$ than in control (73.25\%). Treatments $\mathrm{T}_{2}$ and $\mathrm{T}_{3}$ also exhibited 61.00 $\%, 70.75 \%$ Aspergillus flavus infection, respectively after 10 months of storage $\left(\mathrm{P}_{5}\right)$ in cloth bag $\left(\mathrm{C}_{1}\right)$ indi- cating that these treatments could not substantially reduce the infection of Aspergillus flavus in storage. However, in polythene bag stored seeds $\left(\mathrm{C}_{2}\right)$, the percent seed infection was substantially lower than cloth bag stored seeds $\left(\mathrm{C}_{1}\right)$ in all the treatments and at different periods of storage. The percent Aspergillus flavus infection was minimum $(0.25 \%)$ in $\mathrm{T}_{5}$ and $\mathrm{T}_{4}(0.25 \%)$ in Polythene bag stored seeds $\left(\mathrm{C}_{2}\right)$ (Table 1). Data indicate that $A$. flavus infection increases in polythene bag stored seeds but at slower rate as compared to seeds stored in cloth bag this may be due to that cloth bag allow air to pass through and regulate the seed moisture content according to ambient storage conditions which in turn leads to accelerate the aging process. Monira et al. (2012) also found an increase in fungi on soybean seeds stored in cloth bag and tin container than in poly bag. However, treatments T4 and T5 significantly reduced infection of $A$. flavus infection as compared to other treatments irrespective of seed storage in cloth bag or polythene bag. Ibrahim (2015) also found that soybean treated seeds with vitavax-200 eliminate Aspergillus spp completely and improve seedling vigour characteristics. Upreti (2013) found an increase in Aspergilllus flavus infection of maize seeds stored in cloth bag. Shelar et al. (2015) also found an increase in seed mycoflora as the storage period increases. Monira et al. (2012) also found an increase in fungi on soybean seeds stored in cloth bag and tin container than in poly bag.

\section{Conclusion}

Soybean has a storage problem and performs differently in different environment towards storability. So this work was conducted to study the storage behaviour of soybean in ambient conditions of Pantnagar. With an increase in storage periods, seedling root, shoot length, seedling fresh, dry weight decreases, this decrease was maximum in cloth bag stored seeds as compared to polythene bag stored seeds but Aspergillus flavus increases as period of storage increase. Treatment $T_{2}$ (Flowable thiram @ $2.4 \mathrm{ml} / \mathrm{kg}$ ) and $\mathrm{T}_{5}$ (Polymer + Vitavax $200 @ 2 \mathrm{~g} / \mathrm{kg}$ seed) was found able to maintain all studied parameters to desired level.

\section{REFERENCES}

Ali, M.R., Rahman, M.M. and Ahammad, K.U. (2014). Effect of relative humidity, initial seed moisture content and storage containers on soybean (Glycine $\max \mathrm{L}$. Meril) seed quality. Bangladesh J. Agril. Res., 39(3): 461-469.

Baig, I., Biraderpatil, N. K.,Ninganur, B. T. and Patil, R. H. (2012). Effect of fungicides and polymer coating on storability of soybean seeds. Jawaharlal Nehru Krishi VishwaVidyalaya Res. Journal, 46(1): 78-83.

Directorate of Agriculture. (2015). Statistical data of soybean in Uttarakhand.

F. A. O. (2014). Food and Agriculture Organization. http:// faostat3.fao.org. 
Ibrahim, E. A. M. (2015). Effect of some treatments on seed health and viability of soybean. Plant Pathology Journal, 14(4): 158-167

International Seed Testing Association (ISTA) (2002). International rules for seed testing, Rules 2002; Annexe to chapter 7; Seed health testing methods. Published by ISTA, Bassersdorf, Switzerland.

Islam, M. M., Ahmed, M.,Khalequzzaman, K. M., Reza, M. H. and Iqbal, S. M. (2004). Effects of the types of storage container and storage period on the quality of soybean seeds. Bangladesh Journal of Agricultural Sciences, 31 (1): 71-74

Kakde, R. B. and Chavan, A. M. (2012). Nutritional changes in soybean and safflower oil due to storage fungi. Current Botany, 3(4): 18-23

Kandil A. A., Sharief A. E. and Sheteiwy M. S. (2013). Seedling parameters of soybean cultivars as influenced with seed storage periods, conditions and materials. International Journal of Agriculture Sciences, 5(1):330338

Mohammadi, H., Soltani,A., Sadeghipour, H. R. and Zeinali, E. (2011). Effects of seed aging on subsequent seed reserve utilization and seedling growth in soybean. International Journal of Plant Production, 5 (1): $65-70$

Monira, U.S., Amin, M.H.A.,Aktar, M.M. and Mamun, M. A.A. (2012). Effect of containers on seed quality of storage soybean seed. Bangladesh Research Publications Journal, 7(4):421-427
Motlagh, Z.R. and Shaban, M. (2014). Effect of seed ageing on physiological traits in plants. Scientia Agriculture, 2 (3): 126-129

Nandi, D., Mondal, G.C. and Nandi, B. (1982). Studies on biodeterioration of some oilseeds. III. Effect of different storage temperatures and relative humidities on seed moisture, germinability and infection. Seed Science and Technology, 10:141-150

Radha, B.N., Channakeshava, B.C., Hullur, N., Pandurange, G. K. T., Bhanuprakash K., Ramachandrappa, B. K. and Munirajappa, R. (2013). Effect of seed ageing on protein quality and quantity in maize. International Journal of Bioassays, 3 (1): 1708-1713

Rangaswamy, R. (2014). A Text Book of Agricultural statistics. New Age International Publishers. 351 Pp.

Shelar, V.R., Shaikh, R.S. and Nikam, A.S. (2008). Soybean seed quality during storage: A Review. Agric. Rev., 29 (2):125-131

Shelar, V.R., Mali, M.S. and Nagawade, D.R. (2015). Influence of storage conditions on quality of soybean [Glycine max (L.) Merill] seeds. Journal of Food Legumes, 28(2): 67-71

Tubic, B., Tatic, S., Dordevic, V., Nikolic, Z. and Dukic, V. (2010). Seed viability of oil crops depending on storage conditions. HELIA, 52:153-160

Upreti, K. (2013).Post harvest seed storage in Maize (Zea mays L.): Impact on seed quality, Longevity and seed health. Thesis, Ph.D. G.B. Pant University of Agriculture and Technology, Pantnagar. 